\title{
Cytopathic effects of outer-membrane preparations of enteropathogenic Escherichia coli and co- expression of maltoporin with secretory virulence factor, EspB
}

\author{
SUKUMARAN S. KUMAR, KRISHNAN SANKARAN, RICHARD HAIGH*, PETER H. WILLIAMS* and \\ ARUN BALAKRISHNAN
}

Centre for Biotechnology, Anna University, Chennai - 600 025, India and *Department of Microbiology and Immunology, University of Leicester, UK

\begin{abstract}
Enteropathogenic Escherichia coli (EPEC) is an important aetiological agent of persistent infantile diarrhoea. EPEC pathogenicity is not mediated through known toxins and the role played by outer-membrane proteins (OMPs) in the initial adherence of the bacterium, intimate attachment to epithelial cells and ultimately in the effacement of the intestinal epithelium is being pursued vigorously. In this study of the different cellular fractions of the bacterium investigated, only the outer-membrane fraction was able to disrupt HEp-2 cells. The outer-membrane fraction was also found to be cytotoxic and caused actin accumulation around the periphery of the host cells. To understand the role of OMPs in pathogenesis, protein profiles of outer-membrane preparations of wildtype and attenuated mutants lacking either the EPEC adherence factor (EAF) megaplasmid or EPEC attaching and effacing gene A (eaeA) coding for a 94-kDa OMP, intimin or EPEC secretory protein gene B (espB) coding for a 34-kDa translocated signal transducing protein were compared and correlated with their cytopathic effects. A 43-kDa protein seen along with intimin in the outer membrane of EPEC was identified as maltoporin, an $E$. coli outer-membrane porin normally expressed only in response to maltose in the growth medium. In the case of EPEC, not only was this regulation lost, but also the expression of maltoporin was found to be tightly coupled to the expression of the secretory virulence factor EspB. Maltoporin per se is not toxic, as evidenced by the treatment of HEp-2 cells with the outer-membrane preparation of $E$. coli DH5 $\alpha$ grown in the presence of maltose and the significance of this pathogenic adaptation is not clear. However, when maltoporin and possibly other unidentified proteins were not present as a component of the outer-membrane preparation, as in the outer-membrane preparation of an espB-negative strain, cellular disruption as well as actin accumulation proceeded at a very slow rate even though the cytotoxic effects were comparable to those of the wild-type EPEC strains.
\end{abstract}

\section{Introduction}

Enteropathogenic Escherichia coli (EPEC) is an important cause of persistent infantile diarrhoea. Localised adherence of EPEC cells on to intestinal epithelial cells triggers a signal cascade within the host, which includes phosphorylation of host proteins and translocated bacterial protein(s), elevation in the levels of secondary messengers such as inositol phosphates

Received 18 Oct. 1999; revised version accepted 19 Dec. 2000.

Corresponding author: Professor A. Balakrishnan. and calcium, and cytoskeletal re-arrangements [1-9]. It is believed that these effects collectively result in the formation of an attaching and effacing (AE) lesion of the intestinal epithelium and diarrhoea. The histopathology of the AE lesion reveals cup-like pedestals clasping the pathogen [3].

To understand the molecular mechanism of pathogenesis, it is useful to dissect the pathogenic process into discrete events involving one, two or a few virulenceassociated factors of the pathogen or the host, or both. Pathogenic bacteria elaborate proteins that are directly or indirectly involved in damaging the host. Study of 
EPEC pathogenesis by elegant bacterial genetic techniques by Kaper and others has helped in identifying the roles of some of the essential virulence factors and, accordingly, a three-stage model has been proposed [911]. Some of the genes coding for protein factors, such as the bundle-forming pilus A ( $b f p \mathrm{~A})$ and the plasmidencoded regulatory region (per), are located on a mega-plasmid called the EPEC adherence factor (EAF) $[12,13]$. Expression of the AE phenotype requires the locus of enterocyte effacement (LEE) on the chromosome which contains the EPEC attaching and effacing gene eaeA and other genes such as espB (EPEC secretory protein) $[2,10,11]$. These proteins play important roles in the attachment of the bacteria to the host and in signal transduction processes triggered after initial adherence. Important early biochemical events, as revealed by these studies, emphasise the necessity of intimate surface-surface contact between the host and pathogen and protein translocation through the bacterial type III secretion system into the host $[14,15]$.

To define the role of a virulence factor better, it is necessary to study its effect on the host individually as well as in combination with other virulence proteins. In a whole-cell approach, to understand the role of individual virulence factors of EPEC, scientists have used strains lacking one or more of the known virulence factors. However, cell-free systems such as partially purified bacterial fractions containing one or more virulence factors, as used in this study, could throw additional light on the molecular mechanisms. Cell-free preparations such as whole-cell lysates of Salmonella [16], cell wall preparations of Streptococcus pneumoniae, porins of Shigella and Helicobacter and S-fimbriae of uropathogenic E. coli have helped to understand their cytotoxic and immunomodulatory properties in host cells [17-22]. Recently, it was shown that adherence of EPEC was involved in reducing the resting membrane potential of the gut epithelium by inhibiting metabolically driven pumps, possibly through a surface-associated virulence factor. This model has been proposed to account for the $\mathrm{Na}^{+}$-rich diarrhoea caused by EPEC [23].

This study investigated the effects of outer-membrane preparations of wild-type and mutant EPEC that are deficient in expression of intimin (a 94-kDa outermembrane protein necessary for intimate attachment) or EspB (a 34-kDa secretory protein that the bacterium translocates into the host for signal transduction), or both.

\section{Materials and methods}

\section{Strains}

All strains used in this study, including E2348-69 wildtype EPEC, MAR 001 EAF-negative, CVD206 eaeA- negative and UMD864 espB-negative, were characterised previously by different groups $[1,3,5,6,9-11]$.

\section{Adherence assay}

Adherence was determined as described previously $[24,25]$. HEp-2 cells were grown to $c$. $75 \%$ confluence on coverslips in six-well plates and then infected with EPEC (wild-type, $E A F$-negative, eaeA-negative, espBnegative). Bacteria were grown to late-log phase and $10^{9}$ bacterial cells in $200 \mu \mathrm{l}$ were used to infect the monolayers growing in $2 \mathrm{ml}$ of DMEM medium. After $3 \mathrm{~h}$ at $37^{\circ} \mathrm{C}$ in a $\mathrm{CO}_{2}$ incubator, the medium was aspirated and the monolayers were washed three times with PBS to remove the non-adherent bacteria. The cells, along with the adherent bacteria, were fixed with methanol, stained with Giemsa and observed by oil immersion microscopy. The numbers of bacteria associated with a cell in a localised manner were counted. Based on the number of bacteria associated with 10 different HEp-2 cells in a triplicate assay, the adherence was classified as good, moderate or weak.

\section{Bacterial fractionation}

The secretory proteins were prepared by total ammonium sulphate precipitation of $20 \mathrm{ml}$ of DMEM in which wild-type EPEC was grown to an $\mathrm{OD}_{600}$ of 1.5 . The ammonium sulphate precipitate was dissolved in $2 \mathrm{ml}$ of DMEM and dialysed against $20 \mathrm{mM}$ Tris- $\mathrm{HCl}$, $\mathrm{pH} 7.2$ [26]. To prepare the periplasmic fraction, bacteria were grown to late-log phase in minimal medium containing a sublethal concentration of penicillin $150 \mathrm{U} / \mathrm{ml}$, which results in defective cellwall formation and release of periplasmic contents into the medium. The spent medium was retained as periplasmic preparation. To prepare the membrane and cytosolic fractions, bacteria were grown in Luria Broth (LB) with nalidixic acid $60 \mu \mathrm{g} / \mathrm{ml}$ and subjected to ultrasonication after freezing and thawing. Bacterial pellet from $20 \mathrm{ml}$ of culture was washed once with $2 \mathrm{ml}$ of $20 \mathrm{mM}$ Tris- $\mathrm{HCl}$ containing $10 \mathrm{~mm}$ EDTA, pH 8.0 (TE buffer), resuspended in $2 \mathrm{ml}$ of the same buffer and disrupted by ultrasonication with two 1-min pulses each followed by a 2-min pause. Unbroken cells and debris were removed by centrifugation at $6000 \mathrm{~g}$ for $10 \mathrm{~min}$. The turbid supernate was subjected to ultracentrifugation at $100000 \mathrm{~g}$ for $1 \mathrm{~h}$. The clear supernate was retained as the cytosolic fraction. The pellet, which is the total membrane fraction, was suspended in $1 \mathrm{ml}$ of TE buffer and the protein was estimated by Lowry's method. The protein concentration was adjusted to $5 \mathrm{mg} / \mathrm{ml}$ and solubilised with sodium lauryl sarcosinate $1 \% \mathrm{w} / \mathrm{v}$ (final concentration) at $4^{\circ} \mathrm{C}$ for $1 \mathrm{~h}$. After ultracentrifugation at $100000 \mathrm{~g}$ for $1 \mathrm{~h}$, the supernate was stored as the inner-membrane fraction. The Sarkosyl-insoluble pellet was taken as the outermembrane fraction and was solubilised in $250 \mu \mathrm{l}$ of SDS $1 \% \mathrm{w} / \mathrm{v}$ by heating at $100^{\circ} \mathrm{C}$ for $10 \mathrm{~min}$. For heat inactivation, heating at $100^{\circ} \mathrm{C}$ was prolonged to $30 \mathrm{~min}$. 


\section{SDS-PAGE analysis of fractions}

To verify the purity of the fractions and authenticity of the strains used, SDS-PAGE analysis of the periplasmic and outer-membrane protein (OMP) fractions of the wild-type and the attenuated strains was performed by Laemmli's method with polyacrylamide $10 \%$ gel. The proteins were stained with Coomassie Blue R250.

\section{Cytotoxic effect of the fractions determined by ${ }^{3} H$-thymidine incorporation assay}

A ${ }^{3} \mathrm{H}$-thymidine incorporation assay was performed to evaluate the cytotoxicity of the fractions on HEp-2 cells [27]. Initially, all the fractions of the wild-type EPEC were tested on HEp-2 cells in a dose- and timedependent manner and the amount of ${ }^{3} \mathrm{H}$-thymidine incorporated was measured.

As only the outer-membrane preparation showed cytotoxic effect, this fraction from the wild-type EPEC and the deletion mutants (EAF-negative, eaeA-negative and $\operatorname{esp} B$-negative) was used for detailed study.

\section{Dosage}

Different amounts of the outer-membrane preparation $(5,10,20,40,60,80,100,120,140$ or $160 \mu \mathrm{g})$ in $1 \mathrm{ml}$ of the tissue-culture medium were added to a $75 \%$ confluent layer of HEp-2 cells in a 12 -well plate. Heatinactivated $\left(100^{\circ} \mathrm{C}\right.$ for $\left.30 \mathrm{~min}\right)$ samples $(160 \mu \mathrm{g})$ of the wild-type, the mutant EPEC strains and SDS $1 \%$ were used as controls. ${ }^{3} \mathrm{H}$-Thymidine $(10 \mu \mathrm{Ci})$ was added to each of the wells. At the end of the incubation period $(24 \mathrm{~h})$, the radioactive medium was aspirated and the cells were collected by trypsinisation. After washing sequentially with TCA $10 \%$ and $5 \%$, the pellet was solubilised in $0.1 \mathrm{~N} \mathrm{NaOH}$ containing SDS $0.0025 \%$. The amount of ${ }^{3} \mathrm{H}$-thymidine incorporated was measured with a liquid scintillation counter and the counts were expressed as counts per minute per milligram $(\mathrm{cpm} / \mathrm{mg})$ of protein.

\section{Time-course studies}

To understand the kinetics of the cytotoxic effect, a time-course analysis of the amount of ${ }^{3} \mathrm{H}$-thymidine incorporated into HEp-2 cells exposed to $160 \mu \mathrm{g}$ of outer-membrane preparation was performed. The time points chosen were $30,60,90,120$ and $180 \mathrm{~min}$. The samples were processed and counted as described above.

\section{Morphological changes induced by outer- membrane preparations}

At specific time intervals after exposing the HEp-2 cell monolayers to the outer-membrane preparations (160 $\mu \mathrm{g}$ of protein) of the wild-type and mutant EPEC strains, the cells were observed by phase-contrast microscopy and after $1 \mathrm{~h}$ were fixed with paraformaldehyde $2 \%$ in PBS, stained with Giemsa and then examined by oil immersion microscopy. To test whether maltoporin per se is toxic to HEp-2 cells, the outer-membrane preparation $(160 \mu \mathrm{g})$ of $E$. coli DH5 $\alpha$ grown in the presence of maltose was added and its effect on the host cells was observed. Secretory proteins $(60-160 \mu \mathrm{g}$, equivalent to $160-420 \mu \mathrm{g}$ of outer-membrane preparation) of wild-type EPEC were added to HEp-2 cells and the response elicited was observed as described above.

\section{Fluorescein actin staining (FAS) of HEp-2 cells treated with outer-membrane preparation}

Accumulation of depolymerised actin in host cells at the site of bacterial attachment is characteristic of this enteropathogen. This and the subsequent intimate attachment are known to be mediated by genes coded by the eae operon. FITC phalloidin staining was used to observe actin depolymerisation in HEp-2 cells [5]. HEp-2 cells were exposed to $160 \mu \mathrm{g}$ of outermembrane preparation of the wild-type and mutant EPEC strains for $1 \mathrm{~h}$. The treated monolayers were fixed with paraformaldehyde $2 \%$ in PBS for $30 \mathrm{~min}$ and then permeabilised with Triton-X 100, $0.1 \%$ in PBS for 5 min. After three washes with PBS, the cells were treated with fluorescein isothiocyanate-conjugated phalloidin $5 \mathrm{mg} / \mathrm{ml}$ in PBS. After two washes in PBS to remove any trace of non-specific fluorescence, the cells were examined with a Nikon fluorescence microscope.

\section{$N$-Terminal sequencing of the 43-kDa OMP and its identity}

The OMP of the wild-type EPEC strain was separated by SDS-PAGE on polyacrylamide $10 \%$ gels (prepared from sequence grade reagents purchased from BioRad) and transferred to a PVDF membrane with a Transblot apparatus. After staining with Coomassie Blue, the band corresponding to the $43-\mathrm{kDa}$ protein was cut out and subjected to N-terminal sequencing with a PerkinElmer automated sequencer. The sequence obtained after 10 cycles was compared with protein sequences in the EMBL database.

\section{Regulation of expression of 43-kDa OMP}

The 43-kDa OMP is not expressed by esp $B$-negative mutants. To verify whether $\operatorname{esp} B$ is essential for the expression of this protein, the $\operatorname{esp} B$ gene was introduced into the esp $B$-negative strain UMD864 by transforming with the plasmid pMSD3 (2) containing $\operatorname{esp} B$ by electroporation, and the OMPs were analysed by SDS-PAGE. The expression of a $43-\mathrm{kDa}$ protein in wild-type EPEC, the EAF-negative strain and DH5 $\alpha$ (an E. coli $\mathrm{K} 12$ derivative), in the presence $(4 \mathrm{~g} / \mathrm{L}$ ) and absence of maltose in the medium, was tested by analysing OMPs by SDS-PAGE. 


\section{Results}

Confirmation of the phenotypes of EPEC strains by adherence assay

The behaviour of the wild-type and mutant EPEC strains in this assay was according to their genotypes as reported previously [24, 25]. Whereas the localised adherence of the wild-type EPEC was good (204 SD 63 bacteria/HEp-2 cell), that of the EAF-negative mutant lacking the adherence factor plasmid was weak (25 SD 12 bacteria/HEp-2 cell). The eaeA-negative (73 SD 24 bacteria/HEp-2 cell) and espB-negative (82 SD 28 bacteria/HEp-2 cell) mutants lacking the pathogenicity island genes necessary for intimate attachment showed only moderate adherence.

\section{Differences in SDS-PAGE profiles}

There were no apparent changes in the protein profiles of the inner membrane and the cytosolic fractions among the different strains. Only the outer-membrane preparations showed significant differences in protein profile, as shown in Fig. 1a. The wild-type strain had a prominent $94-\mathrm{kDa}$ protein and a $43-\mathrm{kDa}$ protein in its outer membrane; the eaeA-negative strain lacked the $94-\mathrm{kDa}$ protein, presumably intimin, coded by the eae $A$ gene; in the esp $B$-negative strain, the $43-\mathrm{kDa}$ protein was missing; in the EAF-negative strain both were present in only minor quantities. It is well known that expression of intimin is under positive control of the per locus in the EAF plasmid. However, a major reduction in the expression of the $43-\mathrm{kDa}$ protein, in the absence of this plasmid, indicates a new role of the plasmid in the expression of this protein. The deduced mol. wt of the $\operatorname{esp} B$ gene product is actually $34 \mathrm{kDa}$ and it is a secretory protein. However, the $43-\mathrm{kDa}$ protein is an OMP and its N-terminal sequence (M M I T L R K L P L) was identical to that of maltoporin, a well known transmembrane protein involved in maltose transport in E. coli [28-30]. The fact that a small amount of this protein was seen in the EAF-negative strain indicated that it was coded for by a chromosomal a

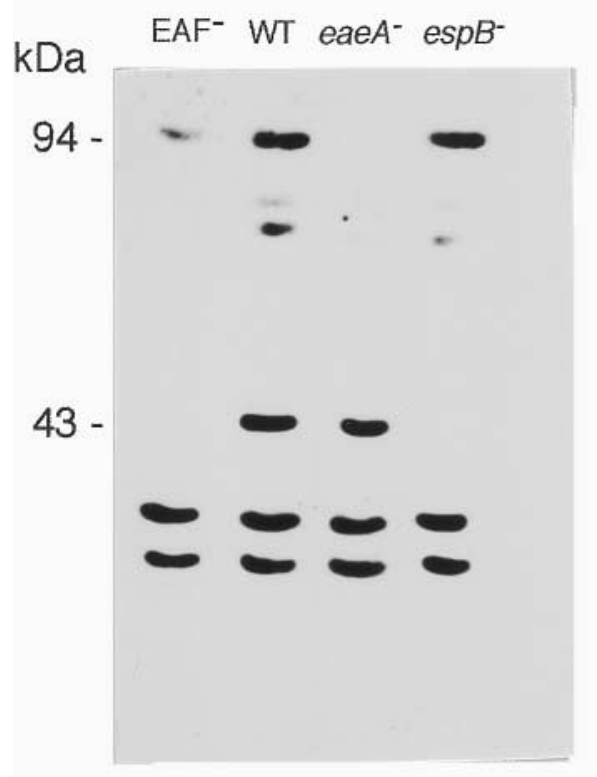

b
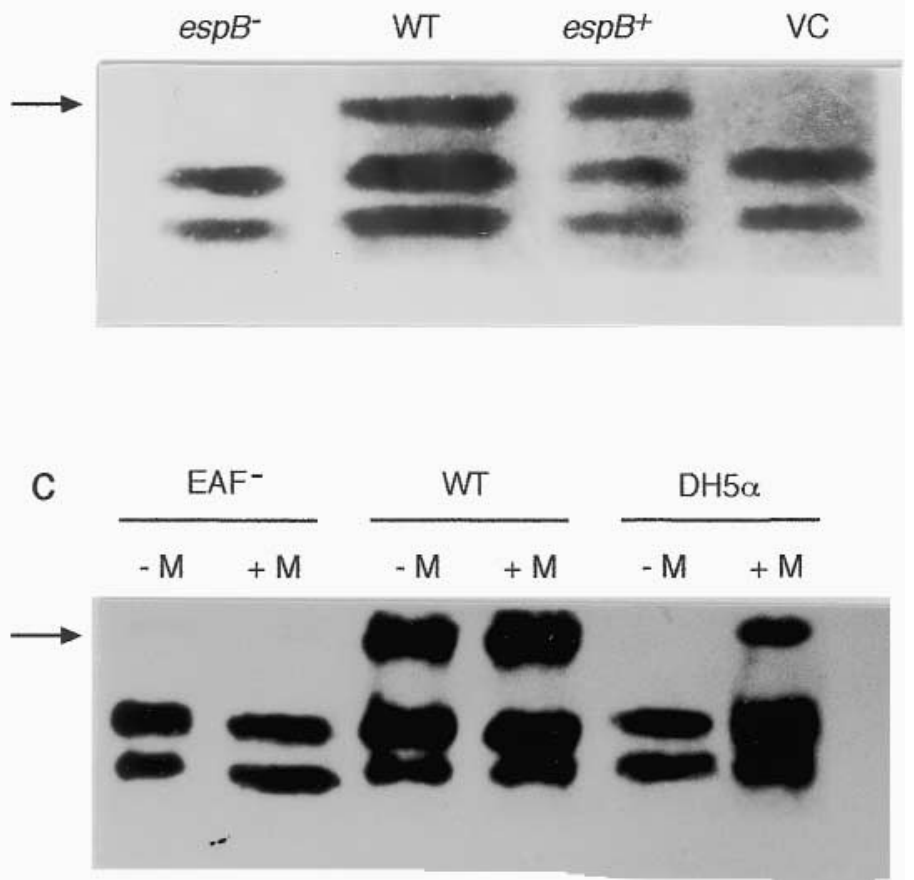

Fig. 1. (a) SDS-PAGE analysis of the outer-membrane fraction from EAF-negative (1), wild-type (lane 2), eaeAnegative (3) and espB-negative (4) strains of E. coli. The $94-\mathrm{kDa}$ intimin, eaeA gene product and the 43-kDa protein are indicated. The $94-\mathrm{kDa}$ protein is expressed well in wild-type and espB-negative strains, poorly in the EAF-negative strain and not in the eaeA-negative strain. Similarly, the $43-\mathrm{kDa}$ protein is expressed well in wild-type and eaeAnegative strains, poorly in the EAF-negative strain, but not in the esp $B$-negative strain. Proteins $(50 \mu \mathrm{g})$ were loaded in each lane and stained with Coomassie Blue R-250 after electrophoresis. (b) SDS-PAGE analysis of the outer-membrane preparations of the espB-negative (lane 1), wild-type (2), espB+ (3) strains and vector control (esp $B$-negative strain with pACYC184) (4). The tight link between the expression of maltoporin and the presence of the espB gene is indicated by the absence of maltoporin in the $\operatorname{esp} B$-negative strain and the vector control. esp $B+$ expresses maltoporin comparable to wild-type, indicating direct correlation of expression of maltoporin with that of EspB. The 43-kDa maltoporin is indicated by the arrow. (c) SDS-PAGE analysis of OMPs of EPEC and E. coli DH5 $\alpha$ : EAF-negative strain grown in DMEM in the absence (lane 1) and presence (2) of maltose $(4 \mathrm{~g} / \mathrm{L})$; wild-type strain grown in the absence (3) and presence (4) of maltose; strain DH5 $\alpha$, grown in the absence (5) and presence (6) of maltose. It is apparent that the expression of maltoporin in strain DH5 $\alpha$ depends on the presence of maltose in the medium, but this regulation is not observed in wild-type EPEC and in the EAF-negative strain, where the levels of expression of maltoporin remain unaffected in the presence or absence of maltose. 
gene. The finding that it is a maltoporin accounts for this observation.

Densitometric scanning of the gel in Fig. 1a revealed that the $43-\mathrm{kDa}$ protein accounted for $20-24 \%$ of the total outer-membrane preparation. Although co-expression of maltoporin with EspB, as inferred by lack of its expression in the espB-negative mutant and its appearance after transformation of the esp $B$-negative strain with a plasmid containing $\operatorname{esp} B$ has been highlighted in this study, it is plausible that there are other undetected or unresolved proteins. However, analysis after silver staining failed to detect minor proteins regulated in the same manner as maltoporin (data not shown).

\section{Expression of maltoporin linked to the expression of $\operatorname{Esp} B$}

The fact that maltoporin was not detected at all in the esp $B$-negative strain, at low levels in the EAF-negative strain and at high levels in the eaeA-negative and wildtype strains indicates that the essential translocated virulence factor, EspB and maltoporin in the outer membrane of the bacterium, are co-expressed (Fig. 1a). To verify whether this association is fortuitous or otherwise, the $\operatorname{esp} B$-negative strain was transformed with a plasmid containing $\operatorname{esp} B$. The expression of maltoporin in this recombinant strain was restored to wild-type levels (Fig. 1b, lane 3). Maltoporin is an OMP of normal E. coli, induced only when the bacterium is grown in media containing maltose. To verify whether this regulation is operative in EPEC, wild-type and the mutant EAF-negative and espBnegative strains were grown in medium containing maltose. The presence of maltose did not alter the levels of maltoporin (Fig. 1c). In contrast, E. coli DH5 $\alpha$ expressed maltoporin only in the presence of maltose in the medium.

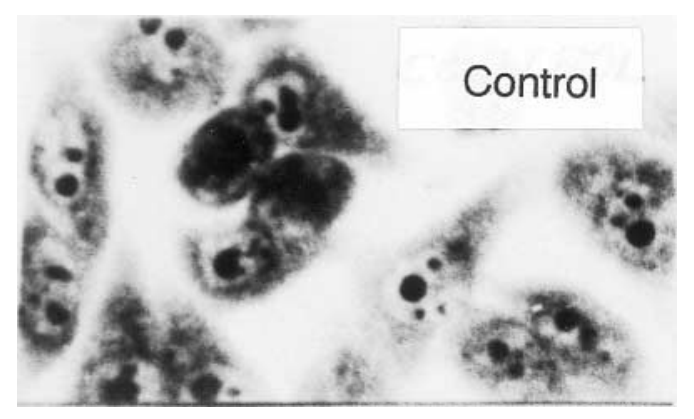

Outer-membrane preparations of EPEC induce morphological changes in the host

Morphological change, such as rounding up of spindleshaped cells, is normally one of the early cytopathic effects caused by the presence of noxious substances in the medium. Hence, this was taken as an indication of the presence of virulence factors that might directly affect host cells. Among the various fractions of the wild-type EPEC, significant changes in the morphology of HEp-2 cells were observed only in the case of the outer-membrane fractions. The periplasmic, cytosolic and inner-membrane fractions did not effect apparent changes in the size or shape of the HEp-2 cells even at very high concentrations (based on protein) or after prolonged treatment for days (data not shown). The morphological changes due to outer-membrane fractions of the wild-type and mutant strains are shown in Fig. 2. Morphological changes were apparent only in the case of wild-type, eae $A$-negative and esp $B$-negative strains, but not in the case of the EAF-negative strain. A time-course study with $160 \mu \mathrm{g}$ of outer-membrane fraction indicated that the spindle-shaped HEp-2 cells gradually rounded up within $20 \mathrm{~min}$ of exposure to preparations from wild-type or eaeA-negative strains and, within $1 \mathrm{~h}$, appeared totally disrupted (Fig. 2). In contrast, it took almost $6 \mathrm{~h}$ before such an effect could be seen with outer-membrane preparation from the esp $B$-negative strain. When the dose of wild-type preparation was reduced to half, it took nearly $2 \mathrm{~h}$ for rounding up of cells to occur and $c .4 \mathrm{~h}$ for disruption (data not shown). It was interesting to observe that on treatment of HEp-2 cells with the outer-membrane preparation from the esp $B$-negative strain transformed with $\operatorname{esp} B$ (Fig. 2, esp $B+1 \mathrm{~h}$ ), an effect similar to that of the wild-type and the eaeA-negative strains was seen. It has been reported that EPEC secretory proteins are not toxic when added to epithelial cells externally (R. Haigh, personal communication); they need to be

Fig. 2. Changes in morphology of HEp-2 cells after treatment for $1 \mathrm{~h}$ with various outer-membrane preparations as revealed by Giemsa staining and observed by oil immersion microscopy $(400 \times)$. HEp-2 cells treated with outermembrane preparations from the wild-type strain (Wild type) and the eaeA-negative (eaeA-) strain appear totally disrupted (rounding up was observed in $20 \mathrm{~min}$ ). The effects of the outer-membrane preparation from the esp $B$-negative strain $(\operatorname{esp} B-1 \mathrm{~h})$ were much slower than the wild-type strain; outer-membrane preparation from the same strain expressing $\operatorname{esp} B$ from a plasmid $(\operatorname{esp} B+1 \mathrm{~h})$ was as disruptive as that of the wild-type strain. However, no change in morphology was seen in HEp-2 cells treated with the outer-membrane preparation from strain DH5 $\alpha$ grown in the presence of maltose $(\mathrm{DH} 5 \alpha \mathrm{M}+)$. The outer-membrane preparation from the EAF-negative strain (EAF-) and the secretory proteins of the wild-type strain $(\mathrm{SP})$ and heat-inactivated $\left(100^{\circ} \mathrm{C}, 30 \mathrm{~min}\right)$ control (HT) did not affect the morphology of the HEp-2 cells even on prolonged exposure. 

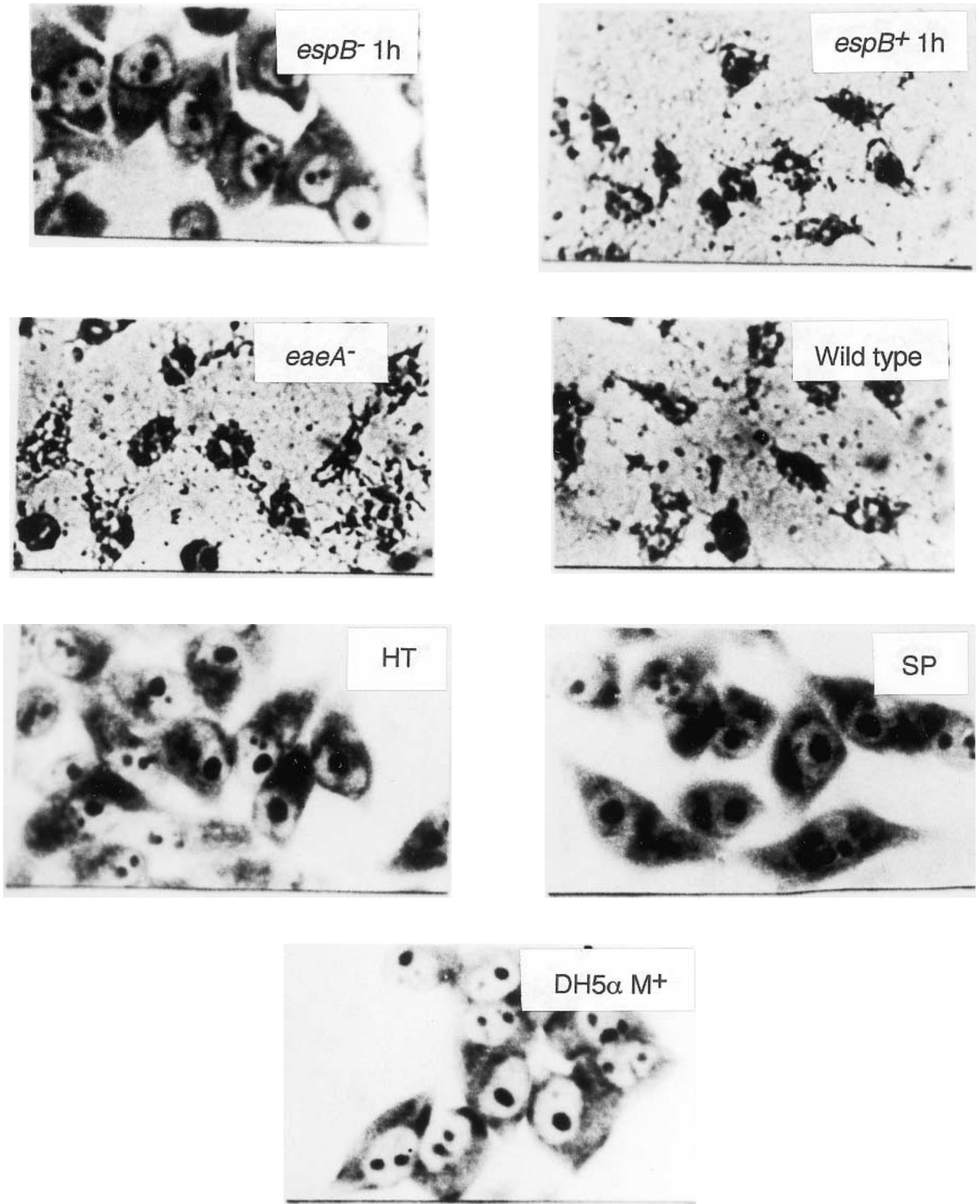

Fig. 2. (Continued).

translocated to the cytosol of the host by the pathogen before exhibiting their cytopathic effects [15]. Similarly in the present study, secretory preparations from wildtype EPEC did not cause any morphological changes when added to HEp2 cells externally. As the outermembrane preparation of the espB-negative mutant lacking maltoporin caused morphological changes only in $c .6 \mathrm{~h}$ compared with $1 \mathrm{~h}$ in the case of the wild-type strain, it raised the possibility that maltoporin may have a role in bringing about a rapid onset of damage. Therefore, the toxicity of maltoporin was tested by exposing HEp-2 cells to outer-membrane preparation from strain $\mathrm{DH} 5 \alpha$ grown in the presence of maltose. There was no significant change in morphology (Fig. 2, $\mathrm{DH} 5 \alpha \mathrm{M}+$ ) even $6 \mathrm{~h}$ after the treatment, indicating that maltoporin alone was not cytopathic. The cellular disruption seen with the outer-membrane fraction is much more severe than that seen with whole bacterial 
infections. This may be an artifact arising from the use of soluble preparations of outer membrane that could trigger damage at multiple points, in contrast to the localised damage caused by EPEC strains.

\section{Cytotoxic effect exhibited by outer-membrane fraction}

Thymidine incorporation helps to monitor the health of a growing and dividing cell. Toxic substances that reduce the viability of a cell cause reduction in the amount of thymidine incorporated into the cell. Therefore, reduction in ${ }^{3} \mathrm{H}$-thymidine incorporation is indicative of the presence of cytotoxic substances in the growth medium. Among the bacterial fractions of the wild-type strain, only the outer-membrane preparation caused a marked decrease in the amount of ${ }^{3} \mathrm{H}$ thymidine incorporated in to HEp-2 cells. Outermembrane preparations from the eaeA-negative and esp $B$-negative strains (Fig. 3) also caused reduction in thymidine incorporation comparable to that of the wildtype strain. In contrast, the outer-membrane fraction from the EAF-negative strain, as well as the heatinactivated $\left(100^{\circ} \mathrm{C}, 30 \mathrm{~min}\right)$ and SDS controls, did not cause any reduction. Many virulence proteins are secretory proteins and their role in EPEC pathogenesis has attracted much attention recently. The secretory protein preparation from wild-type EPEC also did not cause any decrease in the incorporation of ${ }^{3} \mathrm{H}$ thymidine (Fig. 3b, WT, SP). Proteinase K treatment (Fig. 3b, PT) totally abolished the ability of the wildtype outer-membrane fraction to reduce thymidine incorporation. With similar results from the heatinactivated control $\left(100^{\circ} \mathrm{C}, 30 \mathrm{~min}\right)$, these observations support the presumption that the damage is mediated by proteins and not by lipopolysaccharides contaminating the outer-membrane preparation.

In a time-course analysis, reduction in ${ }^{3} \mathrm{H}$-thymidine incorporation was observed within $30 \mathrm{~min}$ of exposure of HEp-2 cells to $160 \mu \mathrm{g}$ of outer-membrane fractions from wild-type, eaeA-negative and espB-negative strains. The dose-response study at $24 \mathrm{~h}$ showed that preparations from wild-type, eaeA-negative (lacking intimin) and esp $B$-negative (lacking maltoporin and possibly other unidentified proteins) strains showed significant cytotoxic effects beyond $60 \mu \mathrm{g}$ with similar potencies. Nearly complete abolition of thymidine incorporation was observed at $100 \mu \mathrm{g}$ for wild-type and at $160 \mu \mathrm{g}$ for eaeA-negative and $e s p B$-negative strains (Fig. 3). The outer-membrane preparation from the EAF- negative strain was not cytotoxic.

\section{FAS in HEp-2 cells treated with outer-membrane fraction}

Originally actin accumulation, at the site of bacterial attachment revealed by staining with FITC phalloidin, was thought to be a hallmark of EPEC pathogenesis and FAS was developed as a diagnostic test [5]. As cellular contact, presumably through outer membrane, is important in the process, the outer-membrane fraction was used to see if it could mimic this effect. In HEp-2 cells treated with the preparations $(160 \mu \mathrm{g})$ from wild-type and eaeA-negative mutant strains, distinct fluorescence was seen around the periphery (necklace pattern) of the cell, indicating the accumulation of depolymerised actin (Fig. 4). The EAF-negative strain, as in the case of untreated HEp-2 cells, did not cause the characteristic fluorescence pattern seen with wild-type outer-membrane fraction. However, the outermembrane fraction from the espB-negative strain was slow in causing actin accumulation. This observation correlates with the slow morphological changes seen with this fraction. Unlike whole bacteria, when the outer-membrane fraction was used actin staining was seen all around the cell. This could be an artifact due to the ability of soluble components to interact at multiple sites along the periphery of the host cell and initiate actin polymerisation, whereas with whole bacteria, actin accumulation can occur only at the site of attachment.

\section{Discussion}

EPEC is non-invasive and does not mediate its pathogenicity through any known toxin. Initially this study aimed to identify possible toxic substances from this pathogen by isolating different cell fractions and treating host cells grown in vitro. Of the cytoplasmic, periplasmic, inner- and outer-membrane fractions of wild-type $E$. coli, only the outer-membrane fraction showed toxic effects. The pathogenesis of EPEC infection involves effacement of the microvilli and intimate attachment of the bacterium to the host cell surface followed by gross cytoskeletal re-arrangements. This direct interaction has been shown to decrease the resting membrane potential in epithelial cells [23] and was proposed as a primary cause for diarrhoea. Very recently, translocation of virulence proteins across the bacterial membranes into the host cytoplasm by a type III secretion system has been demonstrated [14$16,31]$. It is becoming increasingly clear that for EPEC and other pathogens disease begins with intimate contact with cell surfaces and OMPs play a critical role in this process. In the case of EPEC, unlike other invasive pathogens, OMPs serve the additional function of intimately attaching the pathogen to the host surface, thus helping the effective colonisation of the epithelium. The actual attachment process and the molecules involved in EPEC pathogenesis are not yet fully understood.

Outer-membrane preparations were applied directly to HEp-2 cells to monitor various cytotoxic and cytopathic effects normally seen with whole bacteria. Comparative studies with the outer-membrane preparations of strains with mutations in known virulence factors, especially surface-bound (intimin) and extra- 

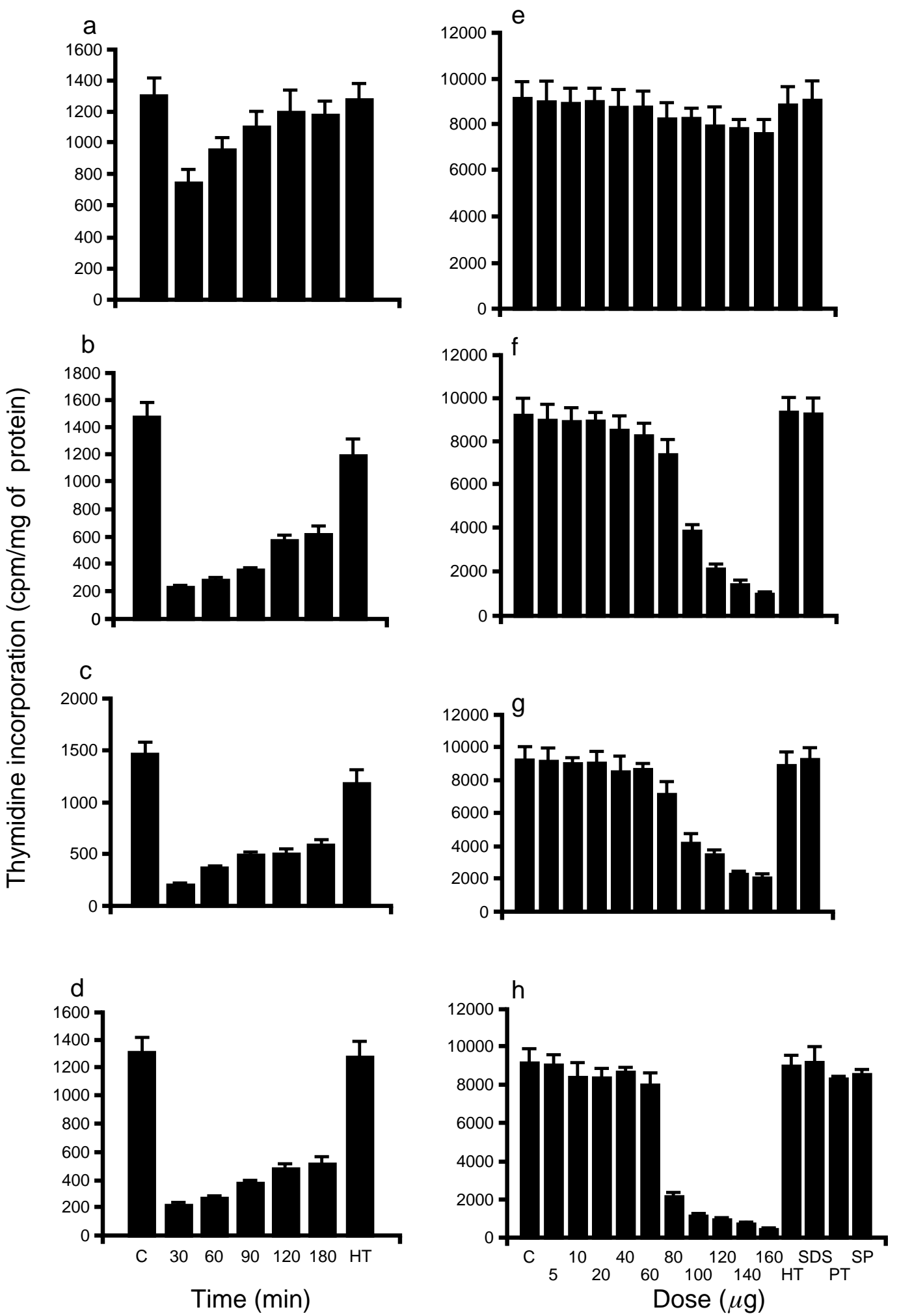

Fig. 3. (a-d) Time course in cytotoxic study. ${ }^{3} \mathrm{H}$-thymidine incorporation expressed as $\mathrm{cpm} / \mathrm{mg}$ of protein by HEp-2 cells treated with $160 \mu \mathrm{g}$ of outer-membrane preparations from the wild-type (d) and mutant EPEC (a, EAF-negative; b, eaeA-negative; c, espB-negative) at different time points. The outer-membrane preparations of the wild-type (d), eaeA-negative (b) and espB-negative (c) strains exhibited a cytotoxic effect on HEp-2 cells within 30 min after addition. C, untreated HEp-2 cells; HT, HEp-2 cells treated with heat-inactivated outer-membrane preparation $\left(100^{\circ} \mathrm{C}\right.$, $30 \mathrm{~min}$ ). (e-h) Dose-response in cytotoxic study. ${ }^{3} \mathrm{H}$-thymidine incorporation, expressed as $\mathrm{cpm} / \mathrm{mg}$ protein in HEp-2 cells treated with varying amounts of outer-membrane preparations from wild-type (h) and mutant EPEC (e, EAFnegative; f, eaeA-negative; g, esp $B$-negative) for 1 day. The preparation from the wild-type strain (h) was found to be cytotoxic above $60 \mathrm{mg}$ as evidenced by major reduction in the incorporated counts; it is nearly $100 \%$ toxic beyond $100 \mu \mathrm{g}$. The outer-membrane preparations of eaeA-negative (f) and espB-negative (g) strains also exhibited similar cytotoxicity. In contrast, the EAF-negative strain (e) did not elicit any toxic response even at $160 \mu \mathrm{g}$. In the controls: $\mathrm{C}$, untreated HEp-2 cells; HT, HEp-2 cells treated with heat-inactivated OMP $\left(100^{\circ} \mathrm{C}, 30 \mathrm{~min}\right)$; SDS, HEp-2 cells treated with SDS corresponding to the amount in the highest dose; PT, proteinase K-treated preparation from the wildtype strain; SP, secretory proteins of the wild-type strain. 

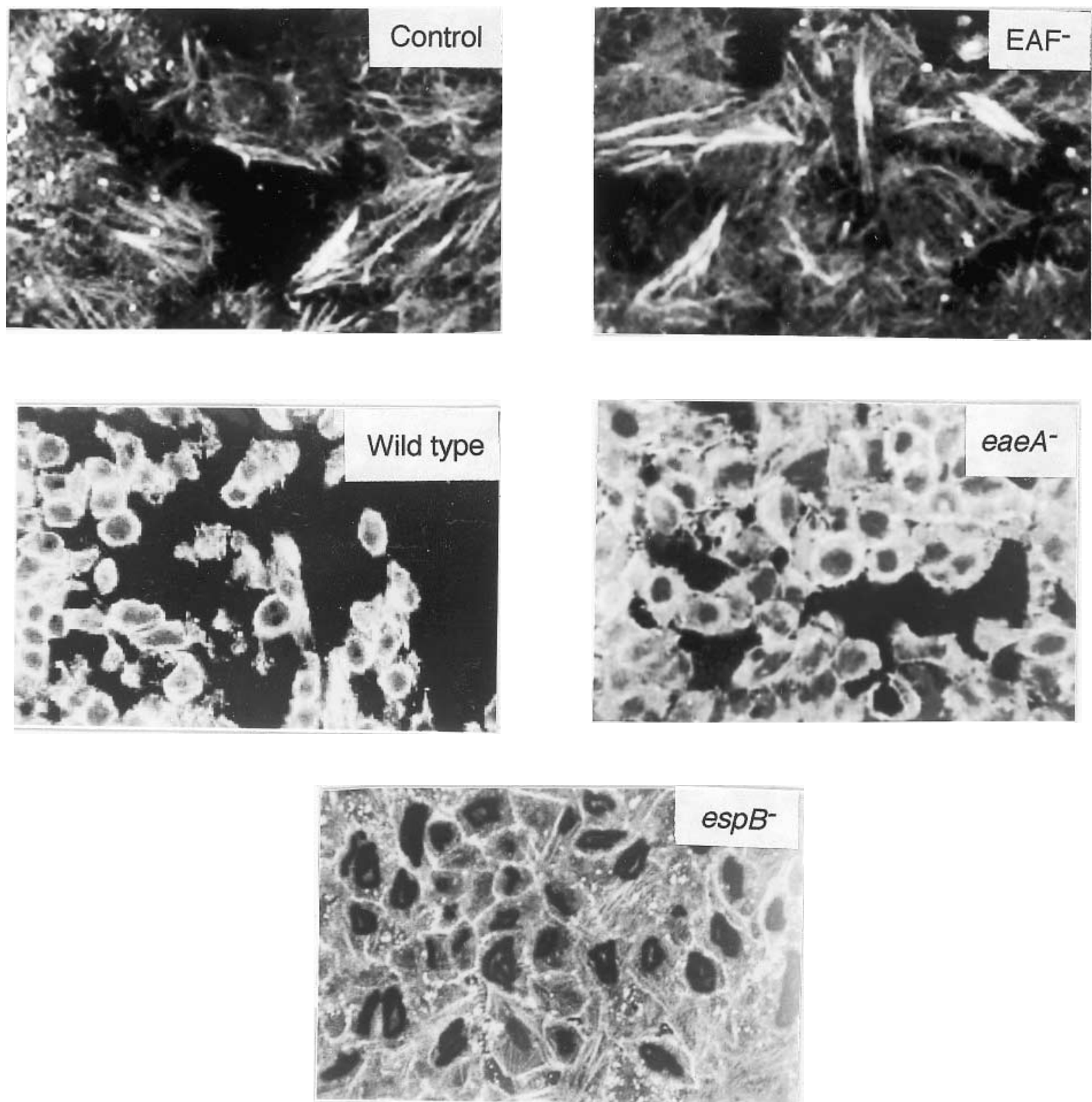

Fig. 4. Fluorescence microscopy (as observed at $400 \times$ ) of fluorescein actin-stained HEp-2 cells treated with the outermembrane preparations from wild-type or mutant EPEC $(160 \mu \mathrm{g})$ for $1 \mathrm{~h}$. The untreated HEp-2 cells (Control) and EAF-negative (EAF-) showed uniform dull fluorescence throughout the cell. In contrast, bright fluorescence was seen along the periphery of the cells treated with the preparation from the wild-type EPEC (Wild type) and eaeA-negative $(e a e A-)$ and $\operatorname{esp} B$-negative (espB-) strains. The magnification of the HEp-2 cells treated with the preparations from wild-type, eaeA-negative and $\operatorname{esp} B$-negative strains has been reduced $(200 \times)$ to visualise a wider range of cells.

cellular (EspB), were performed not only to understand their roles in the process, but also to reveal possible involvement of other outer-membrane constituents. The outer-membrane preparations used in this study were solubilised with SDS $1 \%$ to allow comparison of homogeneous preparations. In preliminary studies with wild-type outer-membrane preparations it was found that even unsolubilised preparations containing outermembrane vesicles were equally cytopathic (data not shown). The amount of outer-membrane preparation (160 $\mu \mathrm{g}$ of protein) was kept high to observe the effect of the preparations from attenuated strains. However, it should be noted that in the case of the wild-type strain, the effects were observed at much lower concentrations.

Whereas the outer-membrane preparations of wild-type and eaeA-negative strains were efficient in causing rounding up and disruption of cells, the outermembrane preparation of the EAF-negative strain did not affect the morphology. More interestingly, the outer-membrane preparation from the esp $B$-negative strain had an effect but took longer to do so. EspB is a secretory protein and not an outer-membrane constituent; however, some reports suggest that most EspB is not secreted and remains behind in the bacteria [31]. 
The reduction in the efficiency of the outer-membrane preparation of the esp $B$-negative strain, compared with the wild-type and eaeA-negative strains, indicated possible differences in their outer-membrane composition. Intimin coded by eaeA did not seem to play a significant role in causing this effect. Recently, investigators have also suggested that EspB may be a part of the translocation apparatus that delivers Tir (translocated intimin receptor) to the host cells and that EspB itself ends up in the host cells [31].

SDS-PAGE analysis of the outer-membrane preparations showed striking differences, as shown in Fig. 1a. The 43-kDa protein seen only in strains that expressed $\operatorname{esp} B$ was further shown to be tightly coupled with $\operatorname{esp} B$ expression by complementation of an espBnegative mutant with $\operatorname{esp} B$ (Fig. 1b). N-Terminal sequencing revealed that this protein is maltoporin, a normal $E$. coli outer-membrane porin induced only in the presence of maltose. However, in the case of EPEC, maltoporin is expressed in rich media such as LB and in tissue-culture medium such as DMEM. Only aged cultures and poorly adherent cultures expressed less. Also, maltose in the medium did not seem to have any effect. The mechanism of co-expression with EspB is not clear; however, according to a recent report, H-NS is necessary for full expression of maltoporin [32]. As global regulators like H-NS are known to be involved in regulating the levels of several virulence factors in this pathogen, there may be a connection between the expression of EspB and maltoporin through a common regulator. As the per locus on the EAF plasmid is needed for the normal expression of intimin in EAFnegative strains, this suggests either a direct or indirect (perhaps through EspB) regulatory role for the per locus. However, more work is needed to unravel the regulatory mechanism behind the co-expression of maltoporin and EspB.

The damage caused by outer-membrane preparation from the wild-type strain may be related in part to the effect of the translocation apparatus of which EspB may be a part. Although not directly revealed in SDSPAGE of OMPs, it is plausible that contamination of outer-membrane preparations with secretory proteins EspA, EspB and EspD might have been responsible for the effects observed. However, it is noteworthy that the secretory protein preparations per se were not cytopathic (Figs. 2 and Fig. 3B).

Co-regulation of maltoporin and the well-known virulence factor EspB might suggest a role for the former in pathogenesis. Maltoporin per se (OMP of strain DH5 $\alpha$ grown in maltose) was non-toxic and except for the EAF-negative strain, outer-membrane preparations of all other strains (wild-type, eaeAnegative and $\operatorname{esp} B$-negative) were cytotoxic to nearly the same extent, indicating that neither intimin nor maltoporin is essential for cytotoxicity. This also may indicate a relationship to the type III secretion system which is intact in the eaeA-negative mutant and is present at low levels in strains cured of the EAF plasmid. If the outer-membrane preparation did not contain maltoporin, as in the case of outer-membrane preparations from the esp $B$-negative mutant, morphological changes and actin polymerisation proceeded very slowly. However, the kinetics improved to nearly wild-type levels when the outer-membrane preparation from the esp $B$-negative mutant that was complemented with $\operatorname{esp} B$ (esp $B+$ positive) was used. This might suggest that either maltoporin, or possibly other unidentified polypeptides (either low mol. wt or expressed in amounts that were not detectable in this system) that may be regulated in the same manner as maltoporin along with EspB, may have a role in hastening the disruption process. Taken together it appears that studies with EPEC mutants in which the maltoporin gene has been deleted or inactivated are needed for understanding the role of maltoporin. These studies are in progress and should provide more insights as to the possible role of maltoporin in EPEC pathogenicity. However, maltoporin is known to mediate the binding of enteroinvasive $E$. coli to basement membrane laminin through high-affinity binding [33]. Maltoporin is also a well-known $\lambda$ phage receptor. Thus, it is tempting to speculate that maltoporin might serve as an additional contact point for bringing bacteria in contact with the host during the infectious processes. It is likely that this interaction, along with other interactions involving virulence proteins, may play a role in host cell disruption. Such a role may also help explain why maltoporin in EPEC is co-expressed with EspB and the normal regulation seen in E. coli has been modified to suit pathogenesis.

Although this study demonstrates that cell-free outermembrane preparations from EPEC are able to cause cytopathic damage to the host cell, the approach taken in this study has helped to identify some of the "normal molecules' that might have been modified in or associated with EPEC pathogenesis, or both. The relevance of these findings to conditions in vivo has to be evaluated. In a typical tissue-culture model, $c$. $10^{9}$ bacteria are added per $10^{6}$ host cells. The soluble preparations of outer membranes used in this study correspond to what is normally obtained from a few thousand bacteria per host cell.

We thank Professors P. Kaliraj and Kunthala Jayaraman for their active support. We also thank the British Council for supporting a collaborative programme with Leicester University through which exchange visits between groups has been made possible, and the L.G Foundation for their assistance. This work was supported by a financial grant from the Department of Science and Technology, New Delhi, India.

\section{References}

1. Baldwin TJ, Ward W, Aitken A, Knutton S, Williams PH. Elevation of intracellular free calcium levels in HEp-2 cells infected with enteropathogenic Escherichia coli. Infect Immun 1991; 59: 1599-1604. 
2. Donnenberg MS, Yu J, Kaper JB. A second chromosomal gene necessary for intimate attachment of enteropathogenic Escherichia coli to epithelial cells. J Bacteriol 1991; 175: 46704680 .

3. Finlay BB, Rosenshine I, Donnenberg MS, Kaper JB. Cytoskeletal composition of attaching and effacing lesions associated with enteropathogenic Escherichia coli adherence to HeLa cells. Infect Immun 1992; 60: 2541-2543.

4. Foubister V, Rosenshine I, Finlay BB. A diarrheal pathogen, enteropathogenic Escherichia coli (EPEC) triggers a flux of inositol phosphates in infected epithelial cells. J Exp Med 1994; 179: 993-998.

5. Knutton S, Baldwin T, Williams PH, McNeish AS. Actin accumulation at sites of bacterial adhesion to tissue culture cells: basis of a new diagnostic test for enteropathogenic and enterohemorrhagic Escherichia coli. Infect Immun 1989; 57: 1290-1298.

6. Baldini MM, Kaper JB, Levine MM, Candy DC, Moon HW. Plasmid-mediated adhesion in enteropathogenic Escherichia coli. J Pediatr Gastroenterol Nutr 1983; 2: 534-538.

7. Baldwin TJ, Brooks SF, Knutton S, Manjarrez Hernansez HA, Aitken A, Williams PH. Protein phosphorylation by protein kinase $\mathrm{C}$ in HEp-2 cells infected with enteropathogenic Escherichia coli. Infect Immun 1990; 58: 761-765.

8. Rosenshine I, Donnenberg MS, Kaper JB, Finlay BB. Signal transduction between enteropathogenic Escherichia coli (EPEC) and epithelial cells: EPEC induces tyrosine phosphorylation of host cell proteins to initiate cytoskeletal rearrangement and bacterial uptake. EMBO J 1992; 11: 3551-3560.

9. Donnenberg MS, Kaper JB. Construction of an eae deletion mutant of enteropathogenic Escherichia coli by using a positive-selection suicide vector. Infect Immun 1991; 59: 4310-4317.

10. Jerse AE, Gicquelais KG, Kaper JB. Plasmid and chromosomal elements involved in the pathogenesis of attaching and effacing Escherichia coli. Infect Immun 1991; 59: 3869-3875.

11. Jerse AE, Kaper JB. The eae gene of enteropathogenic Escherichia coli encodes a 94-kilodalton membrane protein, the expression of which is influenced by the EAF plasmid. Infect Immun 1991; 59: 4302-4309.

12. Girón JA, Ho ASY, Schoolnik GK. An inducible bundleforming pilus of enteropathogenic Escherichia coli. Science 1991; 254: 710-713.

13. Gomez O, Donnenberg MS, Kaper JB. Plasmid encoded regulator $\mathrm{A}(\mathrm{Per})$ is a transcriptional activator of eaeA and $e a e B$ of enteropathogenic Escherichia coli. Abstracts of the 93rd General Meeting, American Society of Microbiology. Washington, DC, American Society for Microbiology. 1993: B310, p. 81.

14. Kenny B, DeVinney R, Stein M, Reinscheid DJ, Frey EA, Finlay BB. Enteropathogenic E. coli (EPEC) transfers its receptor for intimate adherence into mammalian cells. Cell 1997; 91: 511-520.

15. Kenny B, Finlay BB. Protein secretion by enteropathogenic Escherichia coli is essential for transducing signals to epithelial cells Proc Natl Acad Sci USA 1995; 92: 7991-7995.

16. Sears CL, Kaper JB. Enteric bacterial toxins: mechanisms of action and linkage to intestinal secretion. Microbiol Rev 1992
60: $167-215$.

17. Czarny $\mathrm{AD}$, Witkowska, Mulczyk M. Induction of tumour necrosis factor and interleukin- 6 by outer membrane proteins of Shigella in spleen cells and macrophages of mice. Arch Immunol Ther Exp 1981; 41: 153-157.

18. Degre M. Interferons and other cytokines in bacterial infections. J Interferon Cytokine Res 1996; 16: 417-426.

19. Huang J, O'Toole PW, Doig P, Trust TJ Stimulation of interleukin-8 production in epithelial cell lines by Helicobacter pylori. Infect Immun 1991; 63: 1732-1738.

20. Kreft B, Bohnet S, Carstensen O, Hacker J, Marre R. Differential expression of interleukin-6, intracellular adhesion molecule I, and major histocompatibility complex class II molecules in renal carcinoma cells stimulated with $\mathrm{S}$ fimbriae of uropathogenic Escherichia coli. Infect Immun 1992; 61: 3060-3063.

21. Tufano MA, Rossano F, Catalanotti $\mathrm{P}$ et al. Immunobiological activities of Helicobacter pylori porins. Infect Immun 1994; 62: $1392-1399$.

22. Henderson B, Poole S, Wilson M. Bacterial modulins: a novel class of virulence factors which cause host tissue pathology by inducing cytokine synthesis. Microbiol Rev 1996; 60: 316-341.

23. Stein MA, Mathers DA, Yan H, Baimbridge KG, Finlay BB. Enteropathogenic Escherichia coli markedly decreases the resting membrane potential of Caco-2 and HeLa human epithelial cells. Infect Immun 1996; 64: 4820-4825.

24. Scaletsky ICA, Silva MLM, Trabulsi LR. Distinctive patterns of adherence of enteropathogenic Escherichia coli to HeLa cells. Infect Immun 1984; 45: 534-536.

25. Mathewson JJ, Cravioto A. HEp-2 cell adherence as an assay for virulence among diarrheagenic Escherichia coli. J Infect Dis 1989; 159: 1057-1060.

26. Sambrook J, Fritsch, EF, Maniatis T. Molecular cloning: a laboratory manual, 2nd edn. Cold Spring Harbor, NY, Cold Spring Harbor Laboratory Press. 1989.

27. Maya A, Usha S, Nagalakshmi ML, Balakrishnan A. Mitogenic response of rat lung and tracheal epithelial cells in monolayer primary cultures - modulation of $\mathrm{TNF} \alpha$ expression. $J$ Biosci 1991; 19: 207-218.

28. Endermann R, Hindennach I, Henning U. Major proteins of the Escherichia coli outer cell envelope membrane - preliminary characterisation of the phage lambda receptor protein. FEBS Lett 1978; 88: 71-74.

29. Clément JM, Hofnung M. Gene sequence of the lambda receptor, an outer membrane protein of E. coli K12. Cell 1981; 27: $507-514$.

30. Nakae T. A porin activity of purified Lambda-receptor protein from Escherichia coli in reconstituted vesicle membranes. Biochem Biophys Res Commun 1979; 88: 774-781.

31. Wolff C, Nisan I, Hanski E, Frankel G, Rosenshine I. Protein translocation into host epithelial cells by infecting enteropathogenic Escherichia coli. Mol Microbiol 1998; 28: 143-155.

32. Johansson J, Dagberg B, Richet E, Uhlin BE. H-NS and StpA proteins stimulate expression of the maltose regulon in Escherichia coli. J Bacteriol 1998; 180: 6117-6125.

33. Valkonen KH, Veijola J, Dagberg B, Uhlin BE. Binding of basement-membrane laminin by Escherichia coli. Mol Microbiol 1991; 5: 2133-2141. 